that their characters are those of two nearly allied but distinct genera. For his animal he proposes the name of Parmula cocciformis. In 1832, Schlotthauber discovered the animal described by Spix in the neighbourhood of Göttingen, and, following its development, found it to be the larva of Microdon mutabilis. In 1839 he communicated to the Meeting of Naturalists in Pyrmont a full description of the metamorphoses of this species, which he proposed publishing; but it seems never to have been printed.

The author, in 1844, met with bodies resembling coffee-beans, with a reticulated surface, on the inside of the bark of oak-stumps in the Neuhauser Forest, from which he obtained specimens of Microdon mutabilis. He afterwards found single pupæ in similar stumps inhabited by ants, and finally, also a larva, which, however, soon died. M. Sauter has also met with these larvæ; and Dr. Hensche, whilst residing at Kreuth, found amongst earth-dwelling ants three Mollusk-like animals, which he preserved in spirits, and which turned out to be larvæ of Microdon.

As the Microdon mutabilis is a British species, it might interest some of our entomologists to look out for the singular larva here referred to, as the nature of its metamorphosis, and especially its relation to the ants with which it seems to be always associated, appear to be by no means cleared up.-Schriften der Königl. phys.ökon. Gesellschaft zu Königsberg, 1862, Sitzungsberichte, p. 9.

On a New Species of Bird of the Genus Lipaugus of Boié. By P. L. Sclater, M.A., Ph.D., F.R.S.

\title{
LipaUgus SUbalaris.
}

Viridescenti-olivaceus, dorso imo, ventre et cauda conerascentioribus, cauda fere tota cinerea; crisso albicante; pilei semicristati plumis interne nigris : gutturis et pectoris plumarum scapis conspicue flavicanti-albis : plumis axillaribus et subalaribus late citrino-favis : alis fusco-nigricantibus, extus dorso concoloribus : rostro et pedibus nigris.

Hab. In rep. Equatoriana, ad ripas fl. Napo.

This Lipaugus will be easily recognized by the beautiful bright yellow colour of the axillaries and under wing-coverts and the slightly crested head, the feathers of which are black underneath. In structure it appears to be a member of the group Aulia: the outer and middle toes being completely united to the end of the second phalange, and the form otherwise resembling that of Lipaugus hypopyrrhus. The single example in the collection of the British Museum, acquired in 1857, is labelled "Rio Napo."-Proc. Zool. Soc. May 28, 1861. 


\section{$2 \mathrm{BHL}$ Biodiversity Heritage Library}

Sclater, Philip Lutley. 1862. "On a new species of bird of the genus Lipaugus of Boié." The Annals and magazine of natural history; zoology, botany, and geology $10,80-80$.

View This Item Online: https://www.biodiversitylibrary.org/item/72075

Permalink: https://www.biodiversitylibrary.org/partpdf/60828

\section{Holding Institution}

University of Toronto - Gerstein Science Information Centre

\section{Sponsored by}

University of Toronto

\section{Copyright \& Reuse}

Copyright Status: NOT_IN_COPYRIGHT

This document was created from content at the Biodiversity Heritage Library, the world's largest open access digital library for biodiversity literature and archives. Visit BHL at https://www.biodiversitylibrary.org. 